\title{
Novel method for fabrication of sialon corundum composite ceramics by air atmosphere sintering
}

\author{
Krzysztof DUL ${ }^{\dagger}$ \\ AGH University of Science and Technology, al. A. Mickiewicza 30, 30-059 Cracow, Poland
}

\begin{abstract}
A novel approach was developed for synthesizing sialon in an air atmosphere, and then used to obtain $O^{\prime}$-sialon bonded corundum composite ceramics $\left(\mathrm{O}^{\prime}\right.$-scec) by a sintering reaction process in an air atmosphere. The morphology, microstructure, and properties of the $\mathrm{O}^{\prime}$-scec were investigated. The process of forming sialon by air atmosphere sintering is discussed. It was found that a novel configuration, using fused white alumina, alumina powder, and ferro silicon nitride powder, allowed the synthesis of sialon without a controlled nitrogen atmosphere furnace.
\end{abstract}

(02016 The Ceramic Society of Japan. All rights reserved.

Key-words : Sialon, Air atmosphere, Corundum composite, Sialon matrix

[Received December 16, 2015; Accepted April 14, 2016]

\section{Introduction}

Sialons were discovered in the early $1970 \mathrm{~s}$. Sialon is a generic name for compounds or solid solutions made up of the elements $\mathrm{Si}-\mathrm{Al}-\mathrm{O}-\mathrm{N} .{ }^{1-3)}$ Sialon has various compositions and structures, but the most thoroughly studied are $\beta$-, $\alpha-, \mathrm{O}^{\prime}$ - and $\mathrm{X}$-sialon. ${ }^{4-15)}$ It has been reported that $\beta$-sialon can be prepared by synthesis from natural alumino-silicate minerals, such as clay and pyrophyllite, ${ }^{16)}$ alumino-silicate gels, ${ }^{17)}$ or zeolites (with or without polyacrylonitrile) ${ }^{18), 19)}$ by carbothermal reduction and nitridation processes, such as a self-propagating high-temperature synthesis (SHS) in flowing $\mathrm{N}_{2}$ gas. ${ }^{20)}$ Sialon ceramics are typically produced via high-temperature liquid phase sintering of either a powdered mixture of $\mathrm{Si}_{3} \mathrm{~N}_{4}-\mathrm{AlN}-\mathrm{M}_{x} \mathrm{O}_{y}$, where $\mathrm{M}$ is a metal, such as $\mathrm{Li}, \mathrm{Mg}, \mathrm{Ca}, \mathrm{Y}$, or a rare earth element, or $\mathrm{Si}_{3} \mathrm{~N}_{4}-\mathrm{AlN}-$ $\mathrm{Al}_{2} \mathrm{O}_{3} .{ }^{21-23)}$ The atmosphere during the sintering process plays an important role, and $\mathrm{N}_{2}$ gas at a pressure of around $10^{6} \mathrm{~Pa}$ has become the predominant sintering condition for $\mathrm{Si}_{3} \mathrm{~N}_{4}$ ceramics in industry. ${ }^{24)}$ Many papers have discussed the stability of $\mathrm{Si}_{3} \mathrm{~N}_{4}$ and $\mathrm{Si}-\mathrm{O}-\mathrm{N}$ systems at high temperature in terms of thermodynamics. ${ }^{25)-29)}$ At the present state of knowledge of the synthesis of sialon, one has to conclude that it is necessary to employ a nitrogen flow in the furnace, and that sintering $\mathrm{Si}_{3} \mathrm{~N}_{4}$ and $\mathrm{Al}_{2} \mathrm{O}_{3}$ in an air atmosphere furnace does not lead to the synthesis of sialon.

It was the purpose of this investigation to apply a solid-gas reaction for sintering in an air furnace of an $\mathrm{Si}_{3} \mathrm{~N}_{4}+\mathrm{Al}_{2} \mathrm{O}_{3}$ powder of appropriate composition for preparing corundum composite refractories with a sialon matrix.

\section{Experimental}

Sialon corundum composites were prepared from a high quality white fused alumina (from Almatis), with low $\mathrm{K}_{2} \mathrm{O}$ and $\mathrm{Na}_{2} \mathrm{O}$ content, characterized by a close to zero porosity and a density of $3.90 \mathrm{~g} / \mathrm{cm}^{3}$. Reactive alumina CTC-50 (Almatis $\mathrm{d}_{50}=1.0-2.0$ $\mu \mathrm{m}$ ) and tabular alumina T60 (Almatis $0-0.045 \mathrm{~mm}$ ) were used. Nitrosil 20 (Ferro Silicon Nitride obtained from ferrosilicon 75), supplied by Pechiney Electrometallurgie, was used as a $\mathrm{Si}_{3} \mathrm{~N}_{4}$ bearing raw material. These raw materials were used to create

\footnotetext{
Corresponding author: K. Dul; E-mail: kdul@agh.edu.pl
}

Table 1. Raw materials used in producing the $\mathrm{O}^{\prime}$-sialon bonded corundum composite ceramics

\begin{tabular}{ccccc}
\hline & $\mathrm{d}(\mu \mathrm{m})$ & SCCC-1 $(\%)$ & SCCC-2 $(\%)$ & SCCC-3 (\%) \\
\cline { 2 - 5 } Electrocorundum & $1000-3200$ & 43 & 43 & 43 \\
& $500-1000$ & 18 & 18 & 18 \\
& $32-500$ & 8 & 13 & 9 \\
\hline T-60 & 5 & 3 & 3 \\
CTC-50 & 13 & 12 & 11 \\
Nitrosil 20 & 13 & 11 & 16 \\
\hline
\end{tabular}

the sialon matrix at high temperature. In addition, white fused electrocorundum, ranging in particle size from 32 to $3200 \mu \mathrm{m}$, was added to the mixture. The grain size distribution was determined, according to the methods described by Dinger and Funk, ${ }^{30)}$ for a grain distribution coefficient $\mathrm{n}$ equal to $0.37 \mathrm{CPFT}$ (cumulative percent finer than) distribution. Raw materials were combined in the proportions by mass described in Table 1.

The mixtures were homogenized using an Eirich mixer, and specimens were formed as cylinders with a diameter of $50 \mathrm{~mm}$ and a comparable height, or as bricks $63 \mathrm{~mm} \times 114 \mathrm{~mm} \times 230$ $\mathrm{mm}$. The compaction pressure of $85 \mathrm{MPa}$ was used. The synthesis was carried out with a one-step heat treatment procedure. Green refractory composites were heated up to 1173,1473 , or $1773 \mathrm{~K}$, without nitrogen flow, with a constant heating rate of $10^{\circ} \mathrm{C} \mathrm{min}-1$, heated at a constant temperature for $1 \mathrm{~h}$, and then cooled within the furnace Nabertherm HT16/18.

The microstructure of the polished fracture surface of the sialon corundum composite was examined using a scanning electron microscope (SEM), the ultra high definition NOVA NANO SEM 200. Qualitative and quantitative elemental analysis with energy dispersive X-ray spectroscopy (EDS) was also carried out. The phase composition of the final product was examined by XRD equipment (PANalytical X'Pert Pro MPD) using $\mathrm{Cu}-\mathrm{K} \alpha$ radiation. The specimens were scanned over an angular range of $10^{\circ}<2 \theta<90^{\circ}$. IR studies in the range $4000-400 \mathrm{~cm}^{-1}$ were carried out using a Fourier BIO-RAD FT60V spectrometer. The samples were prepared as $\mathrm{KBr}$ pellets. The bulk density and apparent porosity of the sialon-corundum composites were 
determined according to PN-EN 993-1:1998 (methods of test for dense shaped refractory products). The cold crushing strength of the sialon-corundum composites was determined according to PN-EN 993-5:2001 (methods of test for dense shaped refractory products - Part 5: Determination of cold crushing strength).

\section{Results}

\subsection{Microscopy studies}

A photograph of the surface and cross-section morphology of a brick after firing at $1773 \mathrm{~K}$ for $1 \mathrm{~h}$ in an air atmosphere is shown in Fig. 1. It can be seen that cracks, bubbles, and pits exist on the glaze surface. The cross-section sample shows the typical macrostructure of sccc.

When $\mathrm{Si}_{3} \mathrm{~N}_{4}$ is sintered in an air furnace, there are two different sources of oxygen: one is the oxygen in the powder bed (there exists some $\mathrm{SiO}_{2}$ phase on the $\mathrm{Si}_{3} \mathrm{~N}_{4}$, about 1.5 mass \% oxygen) and another the atmosphere in the kiln, composed of $80 \% \mathrm{~N}_{2}$ gas and $20 \% \mathrm{O}_{2}$ gas $\left(\mathrm{pO}_{2}=2 \times 10^{4} \mathrm{~Pa}\right)$. The important fact is that at a pressure of $\mathrm{pO}_{2}=2 \times 10^{4} \mathrm{~Pa}\left(\mathrm{~N}_{2}=8 \times 10^{4} \mathrm{~Pa}\right)$, silicon nitride changes to $\mathrm{SiO}_{2}$ by passive oxidation as shown in reaction (1). The passive oxidation of $\mathrm{Si}_{3} \mathrm{~N}_{4}$ ceramics is mainly influenced by the protective layer formed at the surface by the oxidation process, and the ability of this layer to prevent oxygen from diffusing into the material. A surface layer of pure $\mathrm{SiO}_{2}$ causes a very low rate of oxygen diffusion into the material ${ }^{32}$ )

$$
\mathrm{Si}_{3} \mathrm{~N}_{4}(\mathrm{~s})+3 \mathrm{O}_{2} \rightarrow 3 \mathrm{SiO}_{2}(\mathrm{l})+2 \mathrm{~N}_{2}(\mathrm{~g})
$$

Reaction (2) occurs when $\mathrm{pO}_{2}$ decreases to below $10^{2} \mathrm{~Pa}$, active oxidation takes place

$$
2 \mathrm{Si}_{3} \mathrm{~N}_{4}(s)+3 \mathrm{O}_{2} \rightarrow 6 \mathrm{SiO}(\mathrm{g})+4 \mathrm{~N}_{2}(\mathrm{~g})
$$

The main reaction leading to mass loss of the specimen during sintering is reaction (3). ${ }^{24)}$

$$
\mathrm{Si}_{3} \mathrm{~N}_{4}(s)+3 \mathrm{SiO}_{2}(s, l) \rightarrow 6 \mathrm{SiO}(g)+2 \mathrm{~N}_{2}(g)
$$

Reactions (4) and (5) take place in the insulating layer

$$
\begin{aligned}
& 3 \mathrm{Al}_{2} \mathrm{O}_{3}(s)+2 \mathrm{SiO}(\mathrm{g})+2 \mathrm{O}_{2}(\mathrm{~g}) \\
& \quad \rightarrow 3 \mathrm{Al}_{2} \mathrm{O}_{3} \cdot 2 \mathrm{SiO}_{2}(\mathrm{~s})+\frac{1}{2} \mathrm{O}_{2} \\
& \quad 3 \mathrm{Al}_{2} \mathrm{O}_{3}(\mathrm{~s})+2 \mathrm{SiO}_{2}(\mathrm{l}) \rightarrow 3 \mathrm{Al}_{2} \mathrm{O}_{3} \cdot 2 \mathrm{SiO}_{2}(s)
\end{aligned}
$$

(a) oxygen transfers from the interface by diffusion through the boundary layer between the gas phase and the solid phase to the surface;

(b) after oxygen physisorption, chemisorption and surface penetration, as well as oxygen diffusion through the oxide product layer, oxygen reacts with $\mathrm{Si}_{3} \mathrm{~N}_{4}$ to produce $\mathrm{SiO}(\mathrm{g}), \mathrm{Si}(\mathrm{l})$, $\mathrm{Si}(\mathrm{g}), \mathrm{SiO}_{2}$ (1) - the insulating layer is formed which became

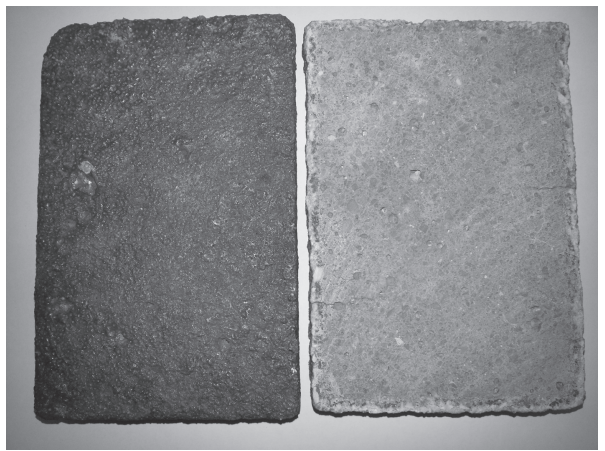

Fig. 1. Macrostructure of bricks; surface and cross-section. impermeable.

Reaction (6) takes place in the bulk ceramic

$$
\begin{aligned}
& 0.51 \mathrm{Si}_{3} \mathrm{~N}_{4}+0.31 \mathrm{SiO}_{2}+0.08 \mathrm{Al}_{2} \mathrm{O}_{3} \\
& \quad \rightarrow \mathrm{Si}_{1.84} \mathrm{Al}_{0.16} \mathrm{O}_{0.16} \mathrm{~N}_{1.84}+0.35 \mathrm{O}_{2}+0.1 N_{2}
\end{aligned}
$$

(c) nitrogen transfer from the bulk of the gas flow to the surface occurs;

(d) the insulating layer stops nitrogen transfer from the surface to the interface.

The macrostructure [Fig. 2(a)] and SEM images of samples near top (insulating) layer [Fig. 2(b)], the transition zone [Fig. 2(c)], and the bulk of the sialon corundum ceramic [Fig. 2(d)] are shown. As can be seen, it comprises two distinguishable parts - the high $\mathrm{O}_{2}$ surface (insulating layer) and the low $\mathrm{O}_{2}$ part located inside the bulk ceramic.

Figure 2(b) shows that the microstructure consists of $\mathrm{Al}_{2} \mathrm{O}_{3}$ grains (points 4 and 5) dispersed in the silicate phases. The glass silicate matrix layer, which was produced by the chemical reaction between $\mathrm{Al}_{2} \mathrm{O}_{3}, \mathrm{Si}_{3} \mathrm{~N}_{4}, \mathrm{O}_{2}$, and $\mathrm{FeSi}_{2}$, contains bright iron oxide dendrites and small, gray mullite crystals. The average chemical composition of phases found in the insulating layer is listed.

The transition zone is clearly distinguished [Fig. 2(c)]. The contrast on backscattered electron micrographs depends mainly on the mean atomic number: pores appear black, $\mathrm{Al}_{2} \mathrm{O}_{3}$ grains appear deep gray, whereas the sialon phase appears gray, the silicate phases appear light gray, whilst iron appears white.

The details of the phases in the bulk region are well illustrated in the SEM image [Fig. 2(d)]. EDS was conducted at six points. $\mathrm{Al}_{2} \mathrm{O}_{3}$ aggregate grains (point 6) are well-bonded by the somewhat porous matrix of sialon (points 1,2 , and 3 ). The microstructure is not pore-free, and has iron accessory phases (points 4 and 5).

To characterize the concentration gradients of the elements $\mathrm{Fe}, \mathrm{Si}, \mathrm{Al}, \mathrm{O}$, and $\mathrm{N}$ in the sialon matrix region, EDS line-scan analysis (in atom \%) was carried out from the locations marked in Fig. 3(a); the outcome is shown in Fig. 3(b). The signal intensity of $\mathrm{N}$ throughout the matrix is higher than the initial line scanning on the $\mathrm{Al}_{2} \mathrm{O}_{3}$ grains, and the line maintains a relatively high intensity in the matrix and gives a strong intensity when it comes into contact with the $\mathrm{Si}_{3} \mathrm{~N}_{4}$ grains. Results show the existence of a dispersed iron phase (the random distribution of elements along the line).

\subsection{Infrared spectroscopy}

The IR spectra of sialon have been discussed. ${ }^{33)}$ In general, the sialon powders differ from each other considerably and also, naturally, from the IR-spectra of silicon nitride and aluminium oxide.

During our IR investigation of the sialon corundum composite, we obtained a spectrum of a matrix before and after sintering in an air atmosphere. This sample showed obvious changes in the IR spectra before and after heating, with increased absorption in the regions near 650 and $900 \mathrm{~cm}^{-1}$ (Fig. 4). In the range 930$1050 \mathrm{~cm}^{-1}$, the spectrum of $\mathrm{O}^{\prime}$-sialon most closely resembles that of silicon nitride; absorption can be associated with $\mathrm{Si}-\mathrm{N}$ vibrations. ${ }^{34), 35)}$ Bands in the area of $650-900 \mathrm{~cm}^{-1}$ appear due to the replacement of $\mathrm{Al}-\mathrm{O}$ and $\mathrm{Si}-\mathrm{N}$ bonds with $\mathrm{Al}-\mathrm{N}$ bonds. $\mathrm{Al}-\mathrm{N}$ stretching occurs in the $700-760 \mathrm{~cm}^{-1}$ region. The IR spectrum at $400-650 \mathrm{~cm}^{-1}$ is a typical spectrum of $\alpha-\mathrm{Al}_{2} \mathrm{O}_{3}$. Characteristic features common to all spectra of $\alpha-\mathrm{Al}_{2} \mathrm{O}_{3}$ are the occurrence of two strong bands near 600 and $650 \mathrm{~cm}^{-1}$; they were assigned to $\mathrm{Al}-\mathrm{O}$ stretching vibrations of $\mathrm{AlO}_{6}$ groups. ${ }^{36)}$ After heating, 


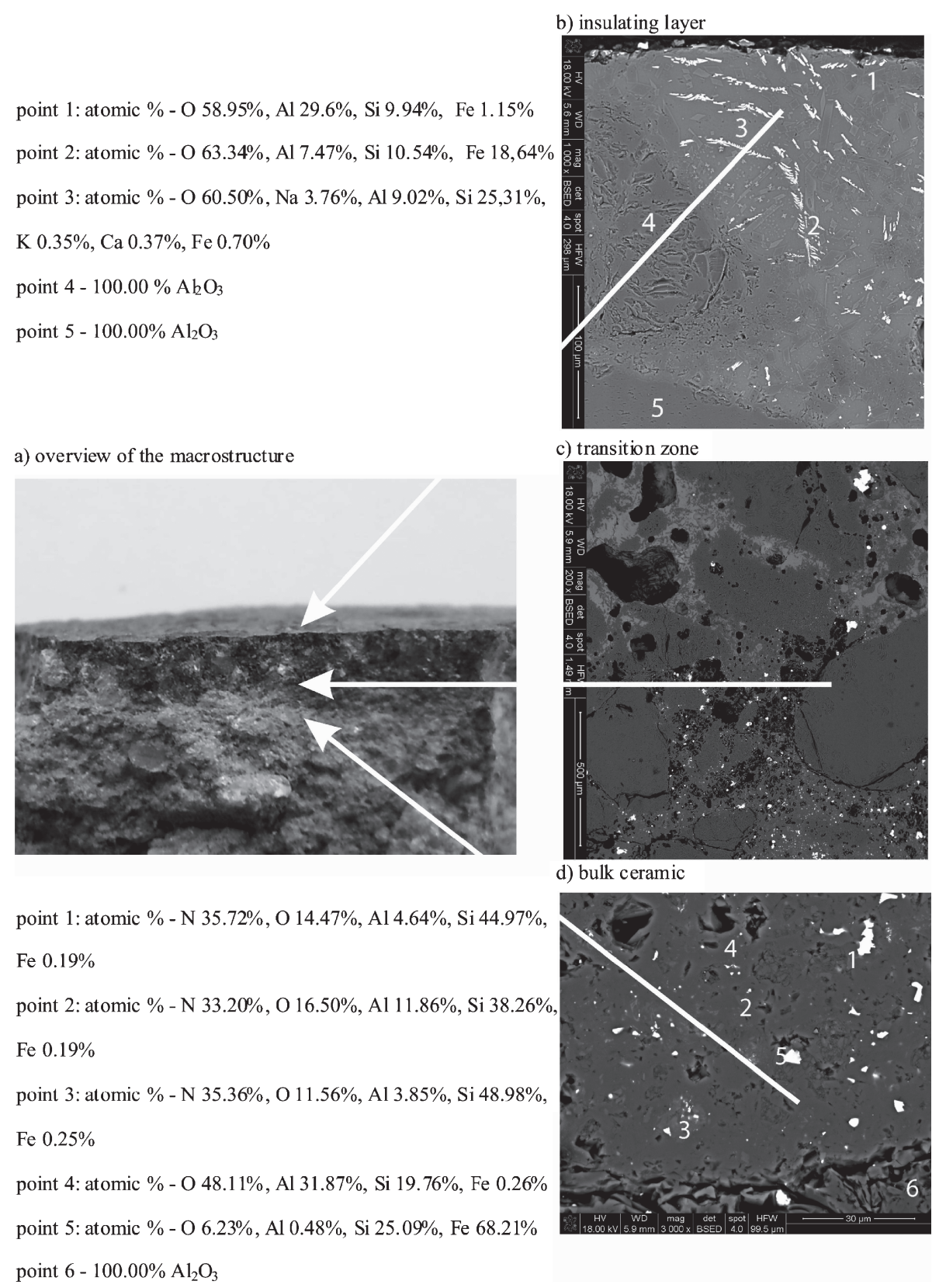

Fig. 2. a) overview of the macrostructure, b) SEM micrographs of insulating layer, c) SEM micrographs of transition zone, d) SEM micrographs of bulk ceramic.

substantial weakening and broadening of the absorption bands of $\alpha-\mathrm{Al}_{2} \mathrm{O}_{3}$ were noted. This testifies to increasing disorder and the destruction of the lattice. Taking into account the data of X-ray phase analysis, the most probable cause of this change must be formation of sialon.

\subsection{X-ray diffraction}

The X-ray powder diffraction pattern of the matrix of sialon after sintering at $1173 \mathrm{~K}$ is shown in Fig. 5(a). Besides the characteristic peaks of $\mathrm{Al}_{2} \mathrm{O}_{3}$, weak diffraction peaks are observed on samples [Fig. 5(b)]. Polycrystalline phases of the samples at 1173, 1473, and $1773 \mathrm{~K}$ (Fig. 6) found by XRD are also summarized in Table 2.

According to this data, the samples formed at 1173 and $1473 \mathrm{~K}$ showed hardly any $\mathrm{O}^{\prime}$-sialon and still had a high amount of silicon nitride. $\mathrm{Si}_{3} \mathrm{~N}_{4}$ under ambient conditions does not melt, but it decomposes into its elements at about $2120 \mathrm{~K}^{37)}$ [Eqs. (7), and (8)]; iron enhances the decomposition, which can start at $973 \mathrm{~K}$ in its presence. ${ }^{38)}$

$$
\begin{aligned}
& \mathrm{Si}_{3} N_{4}(s) \rightarrow 3 \mathrm{Si}(l)+2 \mathrm{~N}_{2}(g) \\
& \mathrm{Si}_{3} N_{4}(s) \rightarrow 3 \mathrm{Si}(g)+2 N_{2}(g)
\end{aligned}
$$

The decomposition of $\mathrm{Si}_{3} \mathrm{~N}_{4}$ at a lower temperature than $2120 \mathrm{~K}$ is confirmed by our work. When using the powder bed technique and air sintering, it is hard to say what is the role of reactions in the gas phase, the effect of nitrogen pressure, or the path of reactions involving atomic nitrogen on the $\mathrm{O}^{\prime}$-sialon formation process. $\mathrm{O}^{\prime}$-sialon could be obtained at $1173 \mathrm{~K}$, but the quantity of $\mathrm{O}^{\prime}$-sialon is low. In the temperature region of 1173 to $1473 \mathrm{~K}$, the content of $\mathrm{O}^{\prime}$-sialon is almost constant and $\mathrm{SiO}_{2}$ was detected. Furthermore an $\alpha \rightarrow \beta-\mathrm{Si}_{3} \mathrm{~N}_{4}$ transformation has been observed. $\mathrm{N}_{2}$ gas is very unreactive, and true gaseous reactions 
a)

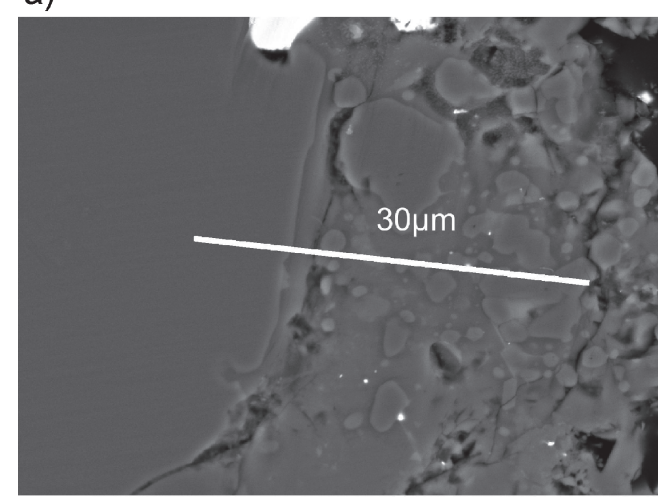

b)

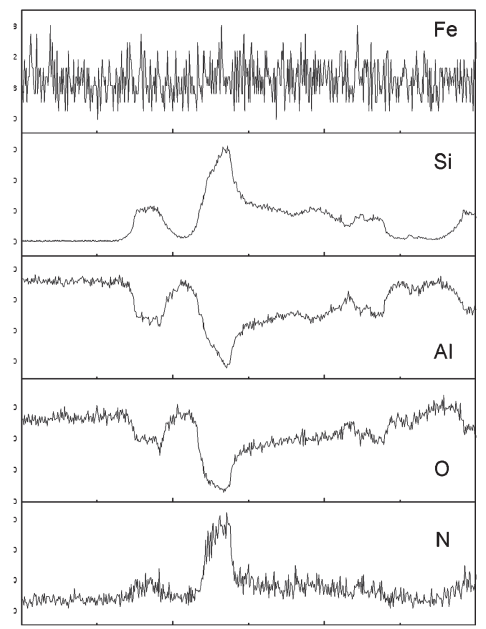

Fig. 3. a) SEM image and line-scan profiles of sample and b) their corresponding atom profile.
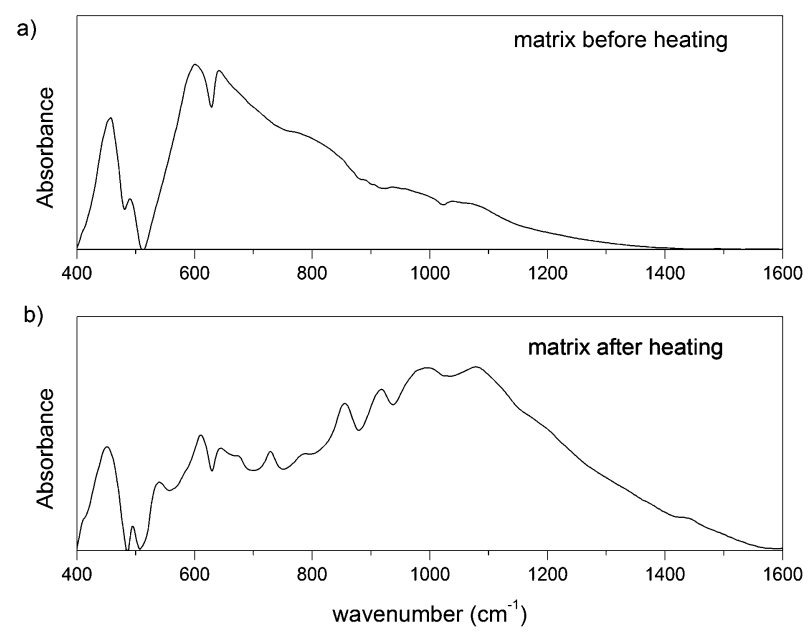

Fig. 4. IR-spectra of samples: a) matrix before heating, b) matrix after heating.

seem unlikely, but it has been reported ${ }^{39), 40)}$ that gas phase reactions can lead to $\beta-\mathrm{Si}_{3} \mathrm{~N}_{4}$. The activation energy separating the two phases, $\alpha$ - and $\beta$ - $\mathrm{Si}_{3} \mathrm{~N}_{4}$, is large. The transformation $\alpha \rightarrow \beta$ $\mathrm{Si}_{3} \mathrm{~N}_{4}$ is reconstructive, ${ }^{41)}$ involving the breaking and remaking of strong $\mathrm{Si}-\mathrm{N}$ bonds.

$$
\alpha-S i_{3} N_{4} \rightarrow \beta-S i_{3} N_{4}
$$
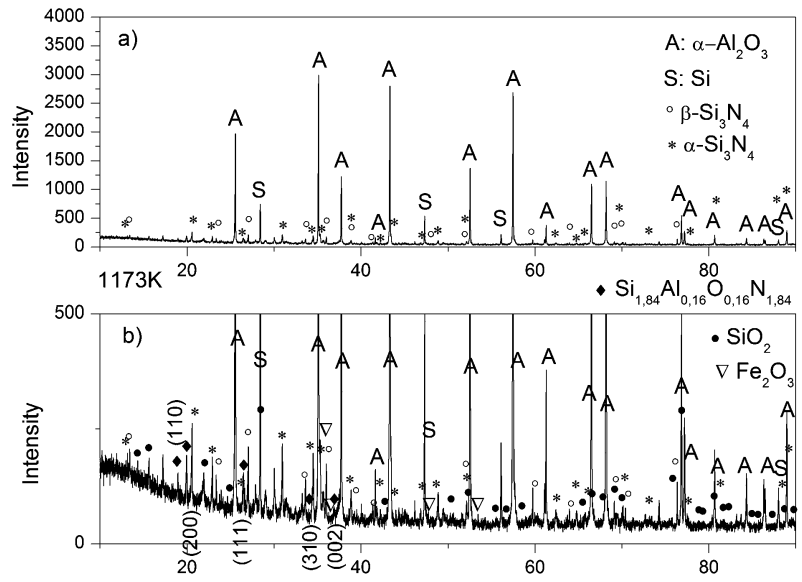

$2 \theta$

Fig. 5. a) XRD patterns matrix of sialon at $1173 \mathrm{~K}$ and b) magnification of XRD spectra.
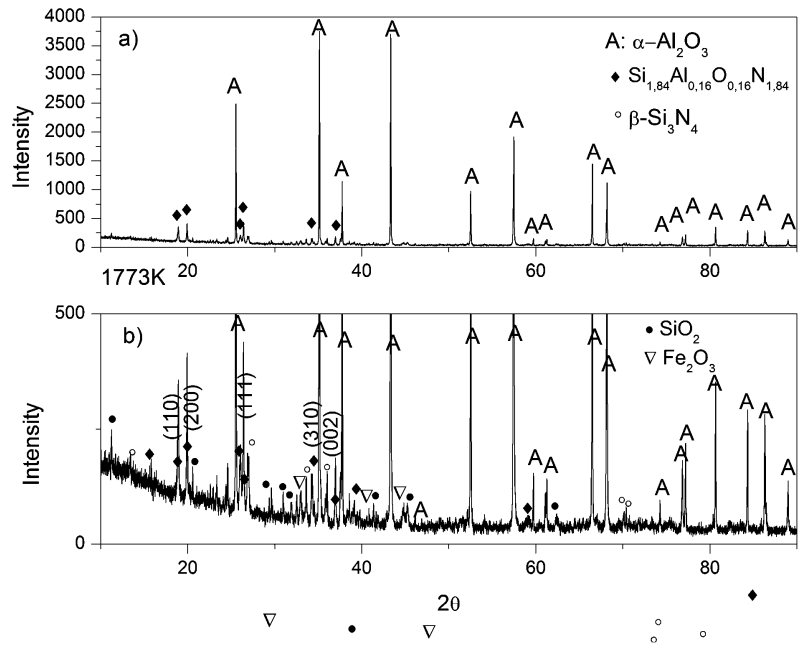

Fig. 6. a) XRD patterns matrix of sialon at $1773 \mathrm{~K}$ and b) magnification of XRD spectra.

Table 2. Phase composition of the sialon-corundum composite ceramic $\frac{\text { Crystalline phases }}{1173 \mathrm{~K} \mathrm{Al} \mathrm{Al}_{2} \mathrm{O}_{3}, \alpha-\mathrm{Si}_{3} \mathrm{~N}_{4}, \mathrm{Si}, \beta-\mathrm{Si}_{3} \mathrm{~N}_{4}, \mathrm{Si}_{1,84} \mathrm{Al}_{0,16} \mathrm{O}_{1,16} \mathrm{~N}_{1,84}, \mathrm{SiO}_{2}, \mathrm{Fe}_{2} \mathrm{O}_{3}}$ $1473 \mathrm{~K} \mathrm{Al} \mathrm{Al}_{2} \mathrm{O}_{3}, \alpha-\mathrm{Si}_{3} \mathrm{~N}_{4}, \mathrm{SiO}_{2}, \beta-\mathrm{Si}_{3} \mathrm{~N}_{4}, \mathrm{Si}, \mathrm{Si}_{1,84} \mathrm{Al}_{0,16} \mathrm{O}_{1,16} \mathrm{~N}_{1,84}, \mathrm{Fe}_{2} \mathrm{O}_{3}$ $\underline{1773 \mathrm{~K} \quad \mathrm{Al}_{2} \mathrm{O}_{3}, \mathrm{Si}_{1,62} \mathrm{Al}_{0,38} \mathrm{O}_{1,38} \mathrm{~N}_{1,62}, \beta-\mathrm{Si}_{3} \mathrm{~N}_{4}, \mathrm{SiO}_{2}, \mathrm{Fe}_{2} \mathrm{O}_{3}}$

XRD analysis showed that, after sintering at $1773 \mathrm{~K}$ (Fig. 6), $\mathrm{O}^{\prime}$ sialon becomes the second phase, besides the main component $\mathrm{Al}_{2} \mathrm{O}_{3}$. For samples heated at $1173-1773 \mathrm{~K}$, it was shown that the $\mathrm{O}^{\prime}$-sialon was synthesized from silicon nitride, aluminium powder, and corundum by nitridation reaction inside the samples, and that the $\mathrm{O}^{\prime}$-sialon bonded corundum composite ceramics were prepared by a pressureless sintering process using air atmosphere sintering.

\subsection{Characteristics of sialon corundum composite ceramics}

Following the results of the microscopy studies, IR spectroscopy, and XRD, we can create a $3 \mathrm{D}$ drawing of the bulk region, ${ }^{42}$ ) which is presented as Fig. 7 (it can be seen as a sialon matrix with hollow areas where corundum grains can be found). 


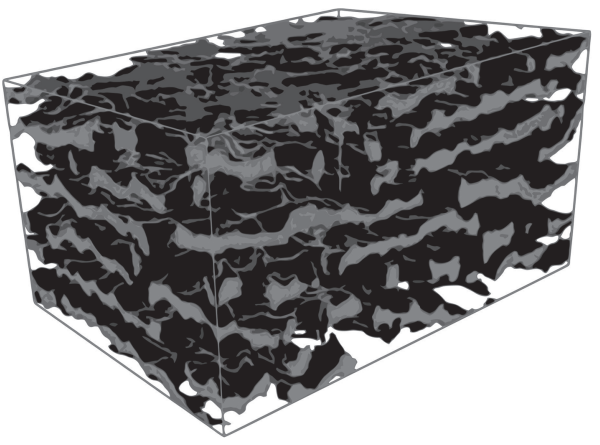

Fig. 7. 3D Drawing of sialon matrix in the bulk region.

Table 3. Properties of sialon corundum composite ceramics

\begin{tabular}{|c|c|c|c|c|c|}
\hline \multicolumn{2}{|c|}{$\begin{array}{l}\text { bulk density } \\
{\left[\mathrm{g} / \mathrm{cm}^{3}\right]}\end{array}$} & \multicolumn{2}{|c|}{$\begin{array}{c}\text { apparent porosity } \\
\text { [vol \%] }\end{array}$} & \multicolumn{2}{|c|}{$\begin{array}{c}\text { cold crushing strength } \\
{[\mathrm{MPa}]}\end{array}$} \\
\hline sccc-1 & literature & scce-1 & literature & scce-1 & literature \\
\hline 3.3 & 3.12 & 8.0 & 14.5 & 140 & 100 \\
\hline
\end{tabular}

On the basis of the above, and Fig. 7, we can say that the improvement in the properties of the sccc could be attributed to increasing density, or the quality and quantity of the $\mathrm{O}^{\prime}$-sialon in the matrix. The key physical properties of our sialon corundum composite ceramic, and a comparison with literature values, ${ }^{43}$ ) are given in Table 3. The results indicate that the open porosity level of scce formed by sintering in air is lower than commercial sialon-bonded corundum ceramics. It is influenced by the oxidation processes, which at $>1373 \mathrm{~K}$ close the pores with the help of an $\mathrm{SiO}_{2}$ surface layer. ${ }^{31)}$ The comparison of our sccc with the commercial sialon-bonded corundum ceramics formed at the same sintering temperature showed an improvement in crushing strength.

\section{Summary}

A novel method of fabrication of $\mathrm{O}^{\prime}$-sialon corundum composite ceramics has been successfully developed. The solid/gas reaction due to the thermal decomposition of $\mathrm{Si}_{3} \mathrm{~N}_{4}$, can be slowed down by embedding the solid in a powder of appropriate composition. The grain size distribution was found to play a significant role in inhibiting volatilization, reducing weight loss, and keeping the microstructure uniform. The accepted wisdom that sintering $\mathrm{Si}_{3} \mathrm{~N}_{4}$ and $\mathrm{Al}_{2} \mathrm{O}_{3}$ in an air furnace cannot give rise to the formation of sialon has been shown to be untrue.

\section{References}

1) Y. Oyama and K. Kamigaito, Jpn. J. Appl. Phys., 10, 16371642 (1971).

2) K. H. Jack, Trans. J. Br. Ceram. Soc., 72, 376-378 (1973).

3) K. H. Jack and W. I. Wilson, Nat. Phys. Sci., 238, 28-29 (1972).

4) V. A. Izhevskiy, L. A. Genova, J. C. Bressiani and F. Aldinger, J. Eur. Ceram. Soc., 20, 2275-2295 (2000).

5) T. Ekström and M. Nygren, J. Am. Ceram. Soc., 75, 259-276 (1992).

6) R. Metselaar, J. Eur. Ceram. Soc., 18, 183-184 (1998).

7) L. J. Gauckler, H. L. Lukas and G. Petzow, J. Am. Ceram. Soc., 58, 346-348 (1975).

8) K. H. Jack, Sci. Ceram., 11, 125-142 (1981).
9) T. Ekström, P. O. Käll, M. Nygren and P. O. Olssen, J. Mater. Sci., 24, 1853-1861 (1989).

10) Z. K. Huang, W. Y. Sun and D. S. Yan, J. Mater. Sci. Lett., 4, 255-259 (1985).

11) S. Hampshire, H. K. Park, D. P. Thompson and K. H. Jack, Nature, 274, 880-883 (1978).

12) D. P. Thompson, Mater. Sci. Forum, 47, 21-42 (1989).

13) O. Lindqvist, J. Sjöberg, S. Hull and R. Pompe, Acta Crystallogr., Sect. B: Struct. Sci., 47, 672-678 (1991).

14) M. Sopicka-Lizer and J. Piekarczyk, Key Eng. Mater., 206213, 429-432 (2001).

15) C. C. Anya and A. Hendry, J. Eur. Ceram. Soc., 10, 65-74 (1992).

16) J. Křestan, P. Šajgalik and Z. Pánek, J. Eur. Ceram. Soc., 24, 791-796 (2004).

17) O. Yamamoto, M. Ishida, Y. Saitoh, T. Sasamoto and S. Shimada, Int. J. Inorg. Mater., 3, 715-719 (2001)

18) Y. Sugahara, H. Hiraiwa, K. Kuroda and C. Kato, J. Mater. Sci., 23, 3181-3186 (1988).

19) F. E. Li, J. Tatami, T. Meguro and K. Komeya, Key Eng. Mater, 247, 109-112 (2003).

20) K. Aoyagi, T. Hiraki, R. Sivakumar, T. Watanabe and T. Akiyama, J. Am. Ceram. Soc., 90, 626-628 (2007).

21) S. J. L. Kang, P. Greil, M. Mitomo and J. H. Moon, J. Am. Ceram. Soc., 72, 1166-1169 (1989).

22) S. I. Hirano, T. Hayashi and T. Nakashima, J. Mater. Sci., 24, 3712-3716 (1989).

23) S. Bandyopadhyay, J. Mukerji and K. Roychoudhury, J. Am. Ceram. Soc., 72, 1061-1064 (1989).

24) S. Wada, J. Ceram. Soc. Japan, 109, 803-808 (2001).

25) G. R. Terwilliger and F. F. Lange, J. Mater. Sci., 10, 1169-1174 (1975).

26) M. Mitomo, J. Mater. Sci., 11, 1103-1107 (1976).

27) N. Wangmooklang, K. Sujirote, S. Jinawath and S. Wada, J. Eur. Ceram. Soc., 27, 2111-2117 (2007).

28) H. D. Batha and E. D. Whitney, J. Am. Ceram. Soc., 56, 365369 (1973).

29) C. Greskovich and S. Prochazka, J. Am. Ceram. Soc., 64, C96C97 (1981).

30) J. E. Funk and D. R. Dinger, Am. Ceram. Soc. Bull., 73, 66-69 (1994).

31) G. Ziegler, J. Heinrich and G. Wötting, J. Mater. Sci., 22, 3041-3086 (1987).

32) H. Klemm, M. Hermann and C. Schubert, J. Eng. Gas Turbines Power, 122, 13-18 (2000).

33) V. N. Antsiferov, V. G. Gilyov and V. I. Karmanov, Vib. Spectrosc., 30, 169-173 (2002).

34) R. K. Brow, C. G. Patano and D. C. Boyd, J. Am. Ceram. Soc., 67, C72-C74 (1984).

35) N. Wada, S. A. Solin, J. Wong and S. Prochazka, J. Non-Cryst. Solids, 43, 7-15 (1981).

36) P. Tarte, Spectrochemica Acta, 23A, 2127-2143 (1967).

37) M. Jansen, "High Performance Non-Oxide Ceramics II", Structure and Bonding vol. 102, Springer-Verlag Berlin Heidelberg (2002).

38) O. Glemser, K. Beltz and P. Naumann, Z. Anorg. Allg. Chem., 291, 51-66 (1957).

39) D. P. Elias and M. W. Lindley, J. Mater. Sci., 11, 1278-1287 (1976).

40) P. E. D. Morgan, J. Mater. Sci., 15, 791-793 (1980).

41) C. M. B. Henderson and D. Taylor, Trans. J. Br. Ceram. Soc., 74, 49-53 (1975).

42) M. Ziętara, A. Kruk, A. Gruszczyński and A. CzyrskaFilemonowicz, Mater. Charact., 87, 143-148 (2014).

43) G. Routschka and H. Wuthnow, "Handbook of Refractory Materials", 4th ed., Essen: Vulkan Verlag (2012). 